\title{
Effectiveness and optimum level of protected methionine in fattening pig diets
}

\author{
Efectividad y nivel óptimo de metionina protegida en dietas para cerdos en engorde \\ Eficácia e nível ideal de metionina protegida em dietas para suínos de engorda
}

José L. Figueroa-Velasco $^{1}$ D; David Trujano-San-Luis ${ }^{1}$ D; José A. Martínez-Aispuro $^{1 *}$ iD; María T. Sánchez-Torres ${ }^{1}$ iD; María M. Crosby-Galván ${ }^{1}$ iD; Agustín Ruíz-Flores ${ }^{2}$ iD; José L. Cordero-Mora ${ }^{1}$ iD.

\footnotetext{
${ }^{1}$ Programa de Ganadería, Campus Montecillo, Colegio de Postgraduados, Montecillo, Texcoco, Estado de México.

${ }^{2}$ Departamento de Zootecnia, Universidad Autónoma Chapingo, Texcoco, Estado de México.
}

To cite this article:

Figueroa-Velasco JL, Trujano-San-Luis D, Martínez-Aispuro JA, Sánchez-Torres MT, Crosby-Galván MM, Ruíz-Flores A, CorderoMora JL. Effectiveness and optimum level of protected methionine in fattening pig diets. Rev Colomb Cienc Pecu 2020; 33(4): 217-227. DOI: https://doi.org/10.17533/udea.rccp.v33n4a02

\begin{abstract}
Background: Methionine (Met) requirements have not been clearly established for fattening pigs due to their metabolic interrelationships and its bioavailability for protein synthesis. Objective: To determine the optimum level of regular crystalline or protected Met in pig diets from nursery to finishing. Methods: A total of 48 crossbred pigs $(11.74 \pm 1.72 \mathrm{~kg}$ of initial body weight) were used. The treatments consisted of adding four levels $(0.00,0.05,0.10,0.15 \%$ in addition to dietary content) and two types of Met (regular and protected) to pig diets. Results: Nursery, Finishing I, and II pigs fed protected Met increased daily feed intake (DFI; $\leq \leq 0.10$ ). Protected Met raised daily weight gain (DWG) in nursery pigs and increased backfat thickness (BT) in nursery and grower pigs $(\mathrm{p} \leq 0.10)$. In Finishing I pigs, protected Met increased DWG and improved carcass characteristics $(\mathrm{p} \leq 0.10)$. In nursery and grower pigs, an extra $0.15 \%$ Met decreased feed:gain ratio (FGR; $\leq \leq 0.10)$. In grower and Finishing II pigs fed extra $0.05 \%$ Met improved DWG and extra $0.10 \%$ Met reduced plasma urea concentration $(\mathrm{p} \leq 0.10)$. Conclusions: Feeding protected Met in pig diets increases DWG, DFI and BT. Increasing 0.05-0.15\% Met level improves FGR, DWG, potentially reducing nitrogen excretion to the environment.
\end{abstract}

Keywords: bioavailability; carcass traits; growth performance; nutrient requirements; pig; protected methionine; protein; swine; synthetic amino acids; urea.

Received: July 27, 2018; accepted: April 14, 2020

*Corresponding Author. km 36.5 Montecillo, Texcoco, Estado de México. C.P. 56230. México. Tel.: 5959520200. Email: alfredo_aispuro@yahoo.com 


\section{Resumen}

Antecedentes: los requerimientos de metionina (Met) para cerdos en crecimiento no han sido claramente establecidos, lo que se debe a sus relaciones metabólicas y su biodisponibilidad para la síntesis proteica. Objetivo: determinar el nivel óptimo de Met regular o protegida en dietas para cerdos en crecimiento. Métodos: Se utilizaron un total de 48 cerdos híbridos $(11,74 \pm 1,72 \mathrm{~kg}$ peso vivo inicial). Los tratamientos consistieron en niveles incrementales $(0,00,0,05,0,10,0,15 \%$ adicionales al contenido de la dieta) y dos tipos de Met (regular y protegida) en la dieta. Resultados: los cerdos en iniciación, Finalización I, y II, alimentados con Met protegida tuvieron un mayor consumo diario de alimento (DFI; $\leq \leq 0,10)$. La Met protegida aumentó la ganancia diaria de peso (DWG) durante la etapa de iniciación, e incrementó el grosor de la grasa dorsal (BT) en iniciación y levante $(\mathrm{p} \leq 0,10)$. Durante Finalización I, la Met protegida aumentó la DWG y mejoró las características de la canal ( $\mathrm{p} \leq 0,10)$. Durante iniciación y levante, $0,15 \%$ extra de Met disminuyó la conversión alimenticia (FGR; $\mathrm{p} \leq 0,10)$. Los cerdos en levante y Finalización II alimentados con $0,05 \%$ extra de Met mejoraron la DWG y con $0.10 \%$ extra de Met redujeron la concentración de urea en plasma $(\mathrm{p} \leq 0,10)$. Conclusiones: el uso de Met protegida incrementa DWG, DFI y BT. El aumento del nivel de Met de 0,05-0,15\% mejora FGR y DWG, y podria disminuir la excreción de nitrógeno al ambiente.

Palabras clave: aminoácidos sintéticos; biodisponibilidad; características de la canal; cerdos; comportamiento productivo; metionina protegida; proteína; requerimientos nutricionales; suínos; urea.

\section{Resumo}

Antecedentes: os requisitos de metionina (Met) para suínos de engorda não foram claramente estabelecidos devido às suas relações metabólicas e sua biodisponibilidade para a síntese de proteínas. Objetivo: determinar o nível ideal de Met regular ou protegida em dietas para suínos de engorda. Métodos: foram utilizados 48 suínos híbridos (11,74 $\pm 1,72$ kg de peso vivo inicial). Os tratamentos consistiram em quatro níveis $(0,00,0,05,0,10,0,15 \%$ mais) e dois tipos (regular e protegida) de Met em dietas para suínos de engorda. Resultados: suínos no início, finalização I e II alimentados com Met protegida aumentaram o consumo diário de ração (DFI; $\mathrm{p} \leq 0,10$ ). Met protegido aumentou o ganho de peso diário (DWG) em suínos na iniciação e, aumentou espessura da gordura dorsal (BT) em suínos em iniciação e crescimento $(\mathrm{p} \leq 0,10)$. Nos suínos finalização I, Met protegido aumentou DWG e melhorou as características do canal $(\mathrm{p} \leq 0,10)$. Para suínos de iniciação e crescimento, $0,15 \%$ extra de Met diminuiu conversão alimentar (FGR; $\mathrm{p} \leq 0,10)$. No crescimento e finalização II, a adição de $0,05 \%$ de Met melhoraram o DWG e com $0,10 \%$ reduziram a concentração de uréia $(\mathrm{p} \leq 0,10)$. Conclusões: o uso de Met protegida melhora DWG, DFI e BT. O nível de Met aumentado de 0,05-0,15\% melhora FGR e DWG; além disso, a excreção de nitrogênio ambiental pode ser diminuída.

Palavras-chave: aminoácidos sintéticos; biodisponibilidade; características de carcaça; comportamento produtivo; metionina protegida; necessidades nutricionais; porcos; proteina; suínos; uréia. 


\section{Introduction}

Methionine (Met) is the second or thirdlimiting aminoacid (AA) in conventional diets for growing pigs, which can lead to its deficiency, reduced availability for protein synthesis and limited growth (Bauchart-Thevret et al., 2009; NRC, 2012; Chen et al., 2014). The Met levels present in most dietary ingredients for pigs are insufficient; thus, it must be provided from a synthetic source (Santos et al., 2011). Additionally, bioavailability and bioefficacy of synthetic DL-Met isomers show inconsistent results in growth performance of pigs (Shen et al., 2014; Kong et al., 2016). These could be attributed to the fact that free synthetic AA are very sensitive to the acidic conditions of the stomach and are rapidly absorbed in the digestive tract (Sato et al., 1984, Stein et al., 2007), decreasing their metabolic efficiency.

Dietary inclusion of protected AA provides resistance to stomach conditions and allows for slow intestinal release, which could help to overcome the above-mentioned limitations (Piva et al., 2007). Protected AA utilization has been reported in ruminants, improving productive performance (Zanton et al., 2014). Protected lysine, in substitution for $\mathrm{HCl} \cdot 1 y s i n e$, enhances the bioavailability of this AA in pig diets without negatively affecting growth performance and carcass characteristics (Prandini et al., 2013).

Supplementing Met to pig diets has been associated with positive effects on the immune system. (Opapeju et al., 2012; de Oliveira et al., 2015). Although pigs can tolerate some shortage or surplus of Met (Pena et al., 2008; Santos et al., 2011; Ying et al., 2015) its excess can affect growth performance and carcass characteristics, while low Met levels can increase fat deposition, reducing protein synthesis (Conde-Aguilera et al., 2014). Appropriate dietary concentration of Met depends on each analyzed variable (Zhang et al., 2013).

The objectives of this study were to determine the optimum level of Met in pig diets and to evaluate the effects of regular synthetic or protected DL-Met on growth performance, carcass characteristics and plasma urea nitrogen (PUN) concentration.

\section{Materials and Methods}

\section{Ethical Considerations}

The experimental procedures followed the standards for ethics, biosafety and animal wellbeing of the Official Mexican Standard (NOM062-ZOO, 1999) for the use of animals in experimentation.

\section{Location}

The experiment was conducted at the Swine Unit of the Experimental Farm of Colegio de Postgraduados, located in Montecillo, State of Mexico ( $98^{\circ} 48^{\prime} 27^{\prime \prime} \mathrm{W}$ and $\left.19^{\circ} 48^{\prime} 23^{\prime \prime} \mathrm{N}\right)$. The climate is temperate, semi-arid, with $15.8{ }^{\circ} \mathrm{C}$ average annual temperature, infrequent frosts, $663.7 \mathrm{~mm}$ average annual rainfall, and 2,250 $\mathrm{m}$ altitude (Estación Agro-Meteorológica, 2016).

\section{Animals and experimental design}

Forty-eight crossbred pigs (Yorkshire $\mathrm{x}$ Landrace $\mathrm{x}$ Duroc) terminal line fattening barrows and gilts $(11.74 \pm 1.72 \mathrm{~kg}$ initial BW) were used in a completely randomized design. The treatments consisted in the dietary supplementation with four levels of Met from two types (protected and regular Met) during four growing stages: Nursery $(0.48,0.53,0.58$, and $0.63 \%)$, Grower $(0.38,0.43,0.48$, and $0.53 \%)$, Finishing I $(0.31,0.36,0.41$, and $0.46 \%)$ and Finishing II $(0.23,0.28,0.33$, and $0.38 \%)$. These levels were obtained by adding synthetic or protected Met to the control diet. The Met concentrations of synthetic Met fulfilled the dietary requirements of Met+Cys suggested by the NRC (2012). The protected Met used contained $85 \%$ encapsulated DL-methionine (Mepron ${ }^{\circledR}$ Evonik Industries, Germany).

\section{Diets and animal handling}

Basal diets contained sorghum-soybean meal and were supplemented with crystalline AA [L-lysine $\cdot \mathrm{HCl}$, DL-methionine (Evonik 
Industries, Parsippany, NJ, USA), L-threonine (Jefo Nutrition Inc, Saint-Hyacinthe, Québec, Canada) and L-tryptophan (CPB Aurum, México, DF)] to meet or exceed the nutritional requirement for each stage of growth (NRC, 2012; Table 1). Pigs were individually housed in $1.2 \times 1.5 \mathrm{~m}$ pens, on concrete floor partially covered with plastic slats, and equipped with a single feeder and a nipple drinker. The animals were injected with a deworming and vitamin product (Endovet polivitaminado ${ }^{\circledR} 15 \mu 1 \mathrm{~kg}^{-1}$ of body weight) before the start of the study. Pens were cleaned and the health of pigs verified throughout the experimental period on a daily basis. Ventilation was provided with curtains. Feed and water were provided ad libitum.

Table 1. Ingredients and nutrient composition of experimental diets.

\begin{tabular}{|c|c|c|c|c|}
\hline \multirow[b]{2}{*}{ Ingredient, \% } & \multicolumn{4}{|c|}{ Stage } \\
\hline & Nursery & Grower & Finishing I & Finishing II \\
\hline Sorghum grain & 68.70 & 77.21 & 81.90 & 90.40 \\
\hline Soybean meal & 26.49 & 18.66 & 14.14 & 6.50 \\
\hline Soybean oil & 1.39 & 1.11 & 1.02 & 0.61 \\
\hline Biolys* & 0.88 & 0.73 & 0.64 & 0.61 \\
\hline DL-Methionine & 0.23 & 0.16 & 0.11 & 0.06 \\
\hline L-Threonine & 0.16 & 0.10 & 0.08 & 0.06 \\
\hline L-Tryptophan & 0.01 & 0.00 & 0.01 & 0.00 \\
\hline Vitamins** & 0.20 & 0.20 & 0.20 & 0.20 \\
\hline Minerals*** & 0.15 & 0.15 & 0.15 & 0.15 \\
\hline Common salt & 0.30 & 0.30 & 0.30 & 0.30 \\
\hline Calcium carbonate & 0.83 & 0.56 & 0.51 & 0.87 \\
\hline Orthophosphate & 0.65 & 0.82 & 0.91 & 0.23 \\
\hline Phytase & 0.01 & 0.01 & 0.01 & 0.01 \\
\hline \multicolumn{5}{|c|}{ Nutrient composition calculated (\%) } \\
\hline Metabolizable energy, Mcal kg-1 & 3.30 & 3.30 & 3.30 & 3.30 \\
\hline Crude protein & 20.00 & 16.83 & 15.00 & 12.06 \\
\hline Lysine & 1.28 & 1.00 & 0.85 & 0.63 \\
\hline Methionine & 0.48 & 0.38 & 0.31 & 0.23 \\
\hline Met + Methionine + Cysteine & 0.71 & 0.57 & 0.48 & 0.36 \\
\hline Threonine & 0.76 & 0.60 & 0.52 & 0.40 \\
\hline Tryptophan & 0.21 & 0.17 & 0.15 & 0.11 \\
\hline Calcium & 0.74 & 0.67 & 0.67 & 0.64 \\
\hline Phosphorus & 0.36 & 0.31 & 0.31 & 0.35 \\
\hline \multicolumn{5}{|c|}{ Nutrient composition determined (\%) } \\
\hline Crude protein & 18.95 & 16.75 & 14.75 & 12.35 \\
\hline Calcium & 0.68 & 0.62 & 0.62 & 0.64 \\
\hline Phosphorus & 0.30 & 0.30 & 0.30 & 0.33 \\
\hline
\end{tabular}

*50.7\% lysine (Biolys ${ }^{\circledR}$ Evonik). **Supplied by kg of feed: 5.0×106 IU vitamin A; 1.0×106 IU vitamin D3; $2.0 \times 104$ IU vitamin E; $2 \mathrm{~g}$ vitamin $\mathrm{K} 3$; $1 \mathrm{~g}$ tiamine; $5 \mathrm{~g}$ de rivoflavin; $2 \mathrm{~g}$ pyridoxine; $25 \mathrm{~g}$ niacin; $15 \mathrm{~g}$ D-calcium panthotenate; $3 \mathrm{~g}$ folic acid; $225 \mathrm{~g}$ choline chloride; $0.3 \mathrm{~g}$ antioxidant; $15 \mathrm{mg}$ B12; $180 \mathrm{mg}$ biotin (REKA® Lapisa Animal Nutrition). *** Supplied by kg of feed: $0.2 \mathrm{~g} \mathrm{Se} ; 0.1 \mathrm{~g} \mathrm{Co} ; 0.3 \mathrm{~g} \mathrm{I} ; 10 \mathrm{~g} \mathrm{Cu} ; 100 \mathrm{~g} \mathrm{Zn} ; 100 \mathrm{~g} \mathrm{Fe} ; 100 \mathrm{~g} \mathrm{Mn} \mathrm{(REKA®} \mathrm{Lapisa} \mathrm{Animal} \mathrm{Nutrition).}$ 


\section{Variables measured}

The variables analyzed were: daily weight gain (DWG), daily feed intake (DFI) and feed:gain ratio (FGR). In addition, on the first and last day of the experiment, the backfat thickness (BT) and longissimus muscle area (LMA) were measured using real time ultrasound (Sonovet 600) with a $3.5 \mathrm{MHz}$ transducer (Medison, Inc., Cypress, California, USA). These data, together with the initial (BWi) and final (BWf) body weight, were used to determine fat free lean gain (FFLG) and lean meat percentage (LMP) using the NPPC equations (Burson and Berg, 2001). At the last day of each stage, blood samples were taken from the vena cava in heparinized tubes (Vacutainer®), then set in ice until centrifuged at 2,500 $\mathrm{g}$ during $20 \mathrm{~min}$ (IEC Centra 8R, International Equipment Company, USA), to separate plasma from cell package. Plasma was transferred to polypropylene tubes and stored in a freezer (EUR251P7W Tappan, Electrolux Home Products North America, USA) at $-20{ }^{\circ} \mathrm{C}$ until determination of PUN concentration by UV spectrophotometry (Spectrophotometer Cary 1E UV-vis, Varian, Australia; Chaney and Marbach, 1962).

\section{Statistical analysis}

The experimental design was completely randomized with a $4 \times 2$ factorial arrangement of treatments. Factors were: four levels and two types of Met (regular and protected). Six replicates per treatment were used. Shapiro-Wilk and Levene's tests were used to check normal distribution and homogeneity of variance for all variables. Data were analyzed with the GLM procedure, and Tukey's test $(\mathrm{p} \leq 0.10)$ was used to compare treatment means (SAS, 2011). Initial body weight was used as a covariate $(\mathrm{p} \leq 0.10)$

\section{Results}

Table 2 presents the growth performance results of nursery pigs. No interaction was found between level and type of Met on growth performance $(\mathrm{p}>0.10)$. The FGR was reduced $(p=0.10)$ with the highest level of Met $(0.63 \%)$. The use of protected Met increased DFI, DWG, BWf and BT $(\mathrm{p}=0.07)$.
Grower pigs consuming the highest levels of Met showed reduced DFI ( $p=0.08$; Table 3 ). A possible interaction was observed between level and type of Met for DFI $(p=0.10)$. The FGR improved $(p=0.05)$ when using 0.48 $0.53 \%$ Met, although the best response by the interaction between Met level and type was observed with $0.53 \%$ of protected Met $(p=0.05)$. The highest DWG $(p=0.10)$ was observed with $0.43 \%$ Met, regardless of Met type $(\mathrm{p}>0.10)$. The PUN was reduced with $0.48 \%$ Met $(p=0.10)$. Protected Met reduced LMP $(p=0.09)$ and increased BT $(p=0.02)$.

Table 4 shows the results of Finishing I pigs. The lowest BT was observed with $0.41-0.46 \%$ regular Met $(\mathrm{p}=0.09)$. Protected Met increased DFI $(p \leq 0.01)$, DWG $(p=0.04)$, FFLG $(p \leq 0.01)$, $\operatorname{LMP}(p=0.07)$, and LMA $(p=0.02)$.

The results of Finishing II pig variables are shown in Table 5. Protected Met increased DFI $(p=0.02)$. The DWG, BWf, and FFLG improved with $0.28 \%$ protected Met $(p=0.02)$. PUN was reduced $(p=0.02)$ using $0.33 \%$ Met, regardless of Met type.

\section{Discussion}

Protected Met increased DWG in nursery and finishing pigs, raised DFI in nursery and finishing pigs, improved FGR in grower pigs, increased BT in nursery and grower pigs, and improved carcass characteristics in Finishing I pigs. Prandini et al. (2013) reported better metabolic efficiency of protected AAs compared with traditional synthetic AAs in pig diets due to slower release and absorption rates, which allows for higher metabolic utilization. Protected Met could increase availability and absorption of this amino acid in pigs (Piva et al., 2007; Schwab and Orway, 2016) leading to better productive performance, including DWG, final BW, and FGR (Opapeju et al., 2012; Shen et al., 2014; Chen et al., 2014). In the present study, the increased digestibility of protected Met possibly led to increased BT evidencing a possible excess and imbalance among AAs, which results in removal and excretion of nitrogen excess and retention of carbon skeletons as fat (García et al., 2010). 
Table 2. Treatment means for growth performance of nursery pigs fed four levels and two types of methionine.

\begin{tabular}{|c|c|c|c|c|c|c|c|c|c|c|c|}
\hline & & DFI & DWG & FGR & BWi & BWf & FFLG & LMP & BT & LMA & PUN \\
\hline \% Met & Met type & $\left(\mathrm{kg} \mathrm{d}^{-1}\right)$ & $\left(\mathrm{kg} \mathrm{d}^{-1}\right)$ & & (kg) & (kg) & $\left(\mathrm{kg} \mathrm{d}^{-1}\right)$ & $(\%)$ & $(\mathrm{mm})$ & $\left(\mathrm{cm}^{2}\right)$ & $\left(\mathrm{mg} \mathrm{dL}^{-1}\right)$ \\
\hline 0.48 & Regular & 0.87 & 0.43 & 2.03 & 11.81 & 23.79 & 0.18 & 45.94 & 4.23 & 11.27 & 13.98 \\
\hline 0.48 & Protected & 0.95 & 0.45 & 2.10 & 11.49 & 24.41 & 0.17 & 45.30 & 4.63 & 11.37 & 15.49 \\
\hline 0.53 & Regular & 0.87 & 0.42 & 2.09 & 12.22 & 23.47 & 0.17 & 46.20 & 4.21 & 11.22 & 16.70 \\
\hline 0.53 & Protected & 0.98 & 0.48 & 2.03 & 11.63 & 25.31 & 0.18 & 44.31 & 4.94 & 11.32 & 14.89 \\
\hline 0.58 & Regular & 0.82 & 0.40 & 2.05 & 11.71 & 23.01 & 0.17 & 46.53 & 3.63 & 10.74 & 13.46 \\
\hline 0.58 & Protected & 0.88 & 0.46 & 1.94 & 11.55 & 24.49 & 0.18 & 45.86 & 4.67 & 11.94 & 13.23 \\
\hline 0.63 & Regular & 0.89 & 0.47 & 1.84 & 12.21 & 25.02 & 0.19 & 45.26 & 4.76 & 11.81 & 12.38 \\
\hline 0.63 & Protected & 0.93 & 0.49 & 1.88 & 11.34 & 25.52 & 0.20 & 46.82 & 4.33 & 12.77 & 15.66 \\
\hline SEM & & 0.05 & 0.03 & 0.07 & 0.87 & 0.88 & 0.01 & 0.64 & 0.32 & 0.62 & 2.13 \\
\hline \multicolumn{12}{|c|}{ Main effects } \\
\hline 0.48 & & 0.91 & 0.44 & $2.07^{\mathrm{a}}$ & 11.65 & 24.11 & 0.17 & 45.63 & 4.43 & 11.33 & 14.77 \\
\hline 0.53 & & 0.93 & 0.45 & $2.06^{\mathrm{a}}$ & 11.92 & 24.39 & 0.17 & 45.26 & 4.57 & 11.27 & 15.80 \\
\hline 0.58 & & 0.85 & 0.42 & $2.00^{\mathrm{ab}}$ & 11.63 & 23.75 & 0.17 & 46.20 & 4.15 & 11.34 & 13.35 \\
\hline 0.63 & & 0.91 & 0.48 & $1.88^{\mathrm{b}}$ & 11.78 & 25.27 & 0.19 & 46.04 & 4.55 & 12.29 & 14.02 \\
\hline \multirow[t]{3}{*}{ SEM } & & 0.04 & 0.02 & 0.04 & 0.60 & 0.59 & 0.01 & 0.43 & 0.22 & 0.41 & 1.25 \\
\hline & Regular & $0.86^{\mathrm{b}}$ & $0.43^{\mathrm{b}}$ & 2.01 & 11.99 & $23.82^{b}$ & 0.17 & 45.99 & $4.21^{\mathrm{b}}$ & 11.26 & 14.13 \\
\hline & Protected & $0.94^{\mathrm{a}}$ & $0.47^{\mathrm{a}}$ & 1.99 & 11.50 & $24.94^{\mathrm{a}}$ & 0.18 & 45.58 & $4.64^{\mathrm{a}}$ & 11.85 & 14.82 \\
\hline SEM & & 0.02 & 0.01 & 0.03 & 0.42 & 0.41 & 0.006 & 0.31 & 0.16 & 0.30 & 0.91 \\
\hline
\end{tabular}

Met, Methionine; DFI, daily feed intake; DWG, daily weight gain; FGR, feed:gain ratio; BWi, initial body weight; BWf, final body weight; FFLG, fat free lean gain; LMP, lean meat percentage; BT, backfat thickness; LMA, Longissimus muscle area; PUN, plasma urea nitrogen concentration; SEM, standard error of the mean. Means with different superscript letters $\left({ }^{a}, b, c, d\right)$ within columns differ statistically $(\mathrm{p} \leq 0.10)$.

In our experiment, an extra $0.10-0.15 \%$ Met was the best level for FGR in nursery and grower pigs. Supplementation with extra $0.02-$ $0.12 \%$ Met has been reported to improve FGR in postweaning and growing pigs (Opapeju et al., 2012; Chen et al., 2014; de Oliveira et al., 2015). This could be explained by met being a functional AA for intestinal growth and function, beyond its role as a precursor for protein synthesis (Wu et al., 2013). In grower pigs, although DFI was reduced with 0.48 and $0.53 \%$ Met, FGR was improved with these levels.

Grower and Finishing II Pigs fed extra $0.05 \%$ Met resulted in higher DWG. In growing pigs, $0.01-0.15 \%$ additional Met reduced DFI, thus improving FGR. In Finishing I pigs, $0.10-0.15 \%$ extra Met reduced BT. In Finishing II pigs, the addition of $0.05 \%$ Met improved FFLG. The Met requirement found in this study is higher than that recommended by the NRC (2012). A higher Met level could represent extra benefits in terms of productive performance. Methionine supplementation $(0.02,0.04$, and $0.06 \%)$ in growing pig diets has resulted in improved daily gain, feed intake (Opapeju et al., 2012), and feed: gain ratio (Opapeju et al., 2012; de Oliveira et al., 2015). On the contrary, a Met deficiency in pigs can lead to lower DWG (Conde-Aguilera et al., 2014), growth suppression of the intestinal mucosa, reduction of intestinal epithelium, and increase of oxidative stress (Bauchart-Thevret et al., 2009; Chen et al., 2014). Several studies have showed that pigs can tolerate some Met deficiency (Santos et al., 2011; Ying et al., 2015) or excess levels in the diet (Pena et al., 2008). 
Table 3. Treatment means for growth performance of grower pigs fed four levels and two types of methionine.

\begin{tabular}{|c|c|c|c|c|c|c|c|c|c|c|}
\hline & & DFI & DWG & FGR & BWf & FFLG & LMP & BT & LMA & PUN \\
\hline \% Met & Met type & $\left(\mathrm{kg} \mathrm{d}^{-1}\right)$ & $\left(\mathrm{kg} \mathrm{d}^{-1}\right)$ & & (kg) & $\left(\mathrm{kg} \mathrm{d}^{-1}\right)$ & $(\%)$ & $(\mathrm{mm})$ & $\left(\mathrm{cm}^{2}\right)$ & $\left(\mathrm{mg} \mathrm{dL}^{-1}\right)$ \\
\hline 0.38 & Regular & $1.58^{\mathrm{abc}}$ & 0.76 & $2.06^{\mathrm{abc}}$ & 48.44 & 0.25 & 41.59 & 7.56 & 20.33 & 17.99 \\
\hline 0.38 & Protected & $1.72^{\mathrm{ab}}$ & 0.73 & $2.34^{\mathrm{a}}$ & 52.63 & 0.28 & 39.73 & 8.35 & 19.92 & 17.05 \\
\hline 0.43 & Regular & $1.78^{\mathrm{a}}$ & 0.82 & $2.15^{\mathrm{ab}}$ & 51.15 & 0.29 & 41.51 & 7.70 & 21.95 & 19.47 \\
\hline 0.43 & Protected & $1.71 \mathrm{a}^{\mathrm{b}}$ & 0.81 & $2.10^{\mathrm{abc}}$ & 51.81 & 0.28 & 40.17 & 8.37 & 20.39 & 15.07 \\
\hline 0.48 & Regular & $1.37^{\mathrm{c}}$ & 0.72 & $1.89^{b c}$ & 51.68 & 0.28 & 40.55 & 7.20 & 20.03 & 14.02 \\
\hline 0.48 & Protected & $1.53^{\mathrm{abc}}$ & 0.75 & $2.04^{\mathrm{abc}}$ & 50.41 & 0.27 & 40.85 & 7.93 & 20.72 & 16.13 \\
\hline 0.53 & Regular & $1.50^{\mathrm{abc}}$ & 0.76 & $1.96^{\mathrm{bc}}$ & 49.92 & 0.26 & 40.82 & 7.32 & 19.86 & 18.10 \\
\hline 0.53 & Protected & $1.41^{\mathrm{bc}}$ & 0.76 & $1.86^{\mathrm{c}}$ & 51.02 & 0.26 & 39.97 & 7.42 & 19.05 & 20.69 \\
\hline SEM & & 0.08 & 0.03 & 0.07 & 2.13 & 0.02 & 0.82 & 0.37 & 0.92 & 1.91 \\
\hline \multicolumn{11}{|c|}{ Main effects } \\
\hline 0.38 & & $1.65^{\mathrm{a}}$ & $0.75^{\mathrm{b}}$ & $2.20^{\mathrm{a}}$ & 50.54 & 0.27 & 40.66 & 7.95 & 20.13 & $17.52^{\mathrm{ab}}$ \\
\hline 0.43 & & $1.75^{\mathrm{a}}$ & $0.82^{\mathrm{a}}$ & $2.13^{\mathrm{ab}}$ & 51.48 & 0.28 & 40.84 & 8.03 & 21.17 & $17.27^{\mathrm{ab}}$ \\
\hline 0.48 & & $1.45^{\mathrm{b}}$ & $0.74^{b}$ & $1.97^{\mathrm{bc}}$ & 51.05 & 0.27 & 40.70 & 7.57 & 20.38 & $15.07^{b}$ \\
\hline 0.53 & & $1.46^{\mathrm{b}}$ & $0.76^{\mathrm{ab}}$ & $1.91^{\mathrm{c}}$ & 50.47 & 0.26 & 40.40 & 7.38 & 19.45 & $19.39^{\mathrm{a}}$ \\
\hline \multirow[t]{3}{*}{ SEM } & & 0.05 & 0.02 & 0.05 & 1.52 & 0.01 & 0.57 & 0.26 & 0.62 & 1.33 \\
\hline & Regular & 1.56 & 0.77 & 2.01 & 50.30 & 0.27 & $41.11^{\mathrm{a}}$ & $7.44^{\mathrm{b}}$ & 20.55 & 17.39 \\
\hline & Protected & 1.60 & 0.76 & 2.09 & 51.46 & 0.27 & $40.18^{b}$ & $8.02^{\mathrm{a}}$ & 20.02 & 17.24 \\
\hline SEM & & 0.03 & 0.01 & 0.03 & 1.04 & 0.01 & 0.38 & 0.17 & 0.44 & 0.89 \\
\hline
\end{tabular}

Met, Methionine; DFI, daily feed intake; DWG, daily weight gain; FGR, feed:gain ratio; BWi, initial body weight; BWf, final body weight; FFLG, fat free lean gain; LMP, lean meat percentage; BT, backfat thickness; LMA, Longissimus muscle area; PUN, plasma urea nitrogen concentration; SEM, standard error of the mean. Means with different superscript letters (a, b, c, d) within columns differ statistically $(\mathrm{p} \leq 0.10)$.

It has been also suggested that Met deficiencies could not affect growth performance, carcass characteristics and protein synthesis due to an adaptation of tissue metabolism when facing insufficient dietary met supply (Castellano et al., 2015). The results of the present study confirm that increasing Met levels improve growth performance variables in pigs. Protein deposition is affected when Met is provided at insufficient levels (de Oliveira et al., 2015); therefore, supplementation of extra Met $(+0.12 \%)$ is required for optimal protein synthesis (Chen et al., 2014). Additionally, proper Met levels might reduce carcass fat content in pigs with Met deficiency (CondeAguilera et al., 2014; Castellano et al., 2015). In our study, adding extra $0.10 \%$ Met in growing and Finishing II pigs reduced PUN. This lower PUN concentration is associated with a lower synthesis and excretion of urea originated by AA excess, indicating better utilization of metabolic nitrogen (Qin et al., 2015).

In conclusion, substituting synthetic Met with protected Met increases DWG and DFI without negatively affecting FGR. Additionally, protected Met could alter lipid metabolism, considering it increases BT. These results indicate that increasing $0.05-0.15 \%$ Met improves FGR, DWG, FFLG, and reduces BT and PUN; potentially reducing the excretion of nitrogen in feces and urine to the environment. 
Table 4. Treatment means for growth performance of Finishing I pigs fed four levels and two types of methionine.

\begin{tabular}{|c|c|c|c|c|c|c|c|c|c|c|}
\hline & & DFI & DWG & FGR & BWf & FFLG & LMP & BT & LMA & PUN \\
\hline$\%$ Met & Met type & $\left(\mathrm{kg} \mathrm{d}^{-1}\right)$ & $\left(\mathrm{kg} \mathrm{d}^{-1}\right)$ & & $(\mathrm{kg})$ & $\left(\mathrm{kg} \mathrm{d}^{-1}\right)$ & $(\%)$ & $(\mathrm{mm})$ & $\left(\mathrm{cm}^{2}\right)$ & $\left(\mathrm{mg} \mathrm{dL}^{-1}\right)$ \\
\hline 0.31 & Regular & 4.44 & 0.83 & 2.99 & 73.62 & 0.27 & 38.63 & $11.06^{\mathrm{a}}$ & 27.73 & 8.31 \\
\hline 0.31 & Protected & 2.70 & 0.94 & 2.92 & 73.98 & 0.31 & 39.31 & $11.50^{\mathrm{a}}$ & 29.14 & 11.60 \\
\hline 0.36 & Regular & 2.55 & 0.81 & 3.15 & 74.19 & 0.27 & 38.21 & $11.22^{\mathrm{a}}$ & 26.74 & 11.97 \\
\hline 0.36 & Protected & 2.54 & 0.86 & 2.95 & 73.70 & 0.29 & 39.21 & $10.13^{\mathrm{ab}}$ & 27.02 & 9.65 \\
\hline 0.41 & Regular & 2.30 & 0.77 & 3.03 & 72.45 & 0.28 & 38.57 & $9.33^{b}$ & 25.67 & 10.22 \\
\hline 0.41 & Protected & 2.56 & 0.74 & 3.01 & 74.94 & 0.30 & 39.09 & $10.50^{\mathrm{ab}}$ & 28.39 & 10.63 \\
\hline 0.46 & Regular & 2.41 & 0.80 & 2.98 & 73.97 & 0.29 & 38.93 & $9.39^{\mathrm{b}}$ & 26.50 & 7.87 \\
\hline 0.46 & Protected & 2.50 & 0.83 & 3.06 & 74.29 & 0.30 & 39.30 & $10.50^{\mathrm{a}}$ & 28.33 & 10.21 \\
\hline SEM & & 0.07 & 0.04 & 0.13 & 1.02 & 0.01 & 0.37 & 0.35 & 0.92 & 1.77 \\
\hline \multicolumn{11}{|c|}{ Main effects } \\
\hline 0.31 & & 2.56 & 0.88 & 2.95 & 73.80 & 0.29 & 38.97 & $11.28^{\mathrm{a}}$ & 28.43 & 9.95 \\
\hline 0.36 & & 2.54 & 0.83 & 3.05 & 73.94 & 0.28 & 38.71 & $10.67^{\mathrm{ab}}$ & 26.88 & 10.81 \\
\hline 0.41 & & 2.43 & 0.80 & 3.02 & 73.69 & 0.27 & 38.83 & $9.92^{\mathrm{b}}$ & 27.03 & 10.43 \\
\hline 0.46 & & 4.45 & 0.82 & 3.02 & 74.11 & 0.30 & 39.12 & $10.10^{\mathrm{b}}$ & 27.42 & 9.04 \\
\hline \multirow[t]{3}{*}{ SEM } & & 0.05 & 0.03 & 0.09 & 0.70 & 0.01 & 0.27 & 0.25 & 0.63 & 1.21 \\
\hline & Regular & $2.42^{\mathrm{b}}$ & $0.80^{\mathrm{b}}$ & 3.04 & 73.56 & $0.27^{\mathrm{b}}$ & $38.58^{\mathrm{b}}$ & $10.25^{\mathrm{b}}$ & $26.66^{\mathrm{b}}$ & 9.59 \\
\hline & Protected & $2.58^{\mathrm{a}}$ & $0.86^{\mathrm{a}}$ & 2.99 & 74.22 & $0.30^{\mathrm{a}}$ & $39.22^{\mathrm{a}}$ & $10.73^{\mathrm{a}}$ & $28.22^{\mathrm{a}}$ & 10.52 \\
\hline SEM & & 0.04 & 0.02 & 0.06 & 0.50 & 0.006 & 0.18 & 0.16 & 0.44 & 0.86 \\
\hline
\end{tabular}

Met, Methionine; DFI, daily feed intake; DWG, daily weight gain; FGR, feed:gain ratio; BWi, initial body weight; BWf, final body weight; FFLG, fat free lean gain; LMP, lean meat percentage; BT, backfat thickness; LMA, Longissimus muscle area; PUN, plasma urea nitrogen concentration; SEM, standard error of the mean. Means with different superscript letters (a, b, c, d) within columns differ statistically $(\mathrm{p} \leq 0.10)$. 
Table 5. Treatment means for growth performance of Finishing II pigs fed four levels and two types of methionine.

\begin{tabular}{|c|c|c|c|c|c|c|c|c|c|c|}
\hline & & DFI & DWG & FGR & BWf & FFLG & LMP & BT & LMA & PUN \\
\hline \% Met & Met type & $\left(\mathrm{kg} \mathrm{d}^{-1}\right)$ & $\left(\mathrm{kg} \mathrm{d}^{-1}\right)$ & & (kg) & $\left(\mathrm{kg} \mathrm{d}^{-1}\right)$ & $(\%)$ & $(\mathrm{mm})$ & $\left(\mathrm{cm}^{2}\right)$ & $\left(\mathrm{mg} \mathrm{dL}^{-1}\right)$ \\
\hline 0.23 & Regular & 2.60 & $0.75^{\mathrm{b}}$ & 3.47 & $95.17^{b}$ & $0.24^{\mathrm{b}}$ & 37.28 & $15.56^{\mathrm{ab}}$ & 33.72 & $14.64^{\mathrm{ab}}$ \\
\hline 0.23 & Protected & 3.04 & $0.78^{\mathrm{ab}}$ & 3.98 & $96.08^{\mathrm{ab}}$ & $0.25^{\mathrm{b}}$ & 38.08 & $14.67^{\mathrm{ab}}$ & 35.24 & $10.04^{\mathrm{ab}}$ \\
\hline 0.28 & Regular & 2.80 & $0.78^{\mathrm{ab}}$ & 3.59 & $96.33^{b}$ & $0.28^{\mathrm{b}}$ & 37.38 & $14.58^{\mathrm{ab}}$ & 33.46 & $13.60^{\mathrm{ab}}$ \\
\hline 0.28 & Protected & 2.99 & $0.97^{\mathrm{a}}$ & 3.10 & $102.14^{\mathrm{a}}$ & $0.39^{\mathrm{a}}$ & 37.55 & $13.74^{\mathrm{ab}}$ & 34.63 & $9.06^{\mathrm{b}}$ \\
\hline 0.33 & Regular & 2.75 & $0.83^{\mathrm{ab}}$ & 3.38 & $97.51^{\mathrm{ab}}$ & $0.28^{\mathrm{ab}}$ & 37.58 & $13.20^{\mathrm{ab}}$ & 33.07 & $9.84^{\mathrm{b}}$ \\
\hline 0.33 & Protected & 2.84 & $0.84^{\mathrm{ab}}$ & 3.41 & $98.02^{\mathrm{ab}}$ & $0.30^{\mathrm{ab}}$ & 36.97 & $16.52^{\mathrm{a}}$ & 34.28 & $9.60^{\mathrm{b}}$ \\
\hline 0.38 & Regular & 2.59 & $0.74^{\mathrm{b}}$ & 3.57 & $94.81^{b}$ & $0.26^{\mathrm{b}}$ & 38.15 & $12.94^{\mathrm{b}}$ & 33.77 & $12.04^{\mathrm{ab}}$ \\
\hline 0.38 & Protected & 2.68 & $0.75^{\mathrm{b}}$ & 3.59 & $95.35^{\mathrm{b}}$ & $0.23^{\mathrm{b}}$ & 27.16 & $14.40^{\mathrm{ab}}$ & 32.24 & $16.44^{\mathrm{a}}$ \\
\hline SEM & & 0.13 & 0.03 & 0.23 & 1.48 & 0.03 & 0.66 & 1.02 & 0.17 & 1.82 \\
\hline \multicolumn{11}{|c|}{ Main effects } \\
\hline 0.23 & & 2.82 & $0.76 \mathrm{~b}$ & 3.72 & $95.62^{b}$ & $0.24^{b}$ & 37.68 & 15.11 & 34.48 & $12.34^{\mathrm{ab}}$ \\
\hline 0.28 & & 2.90 & $0.88^{\mathrm{a}}$ & 3.34 & $99.24^{\mathrm{a}}$ & $0.33^{\mathrm{a}}$ & 37.46 & 14.16 & 34.05 & $11.33^{\mathrm{ab}}$ \\
\hline 0.33 & & 2.80 & $0.83^{\mathrm{ab}}$ & 3.40 & $97.77^{\mathrm{ab}}$ & $0.29^{\mathrm{ab}}$ & 37.28 & 14.86 & 33.68 & $9.72^{\mathrm{b}}$ \\
\hline 0.38 & & 2.63 & $0.75^{\mathrm{b}}$ & 3.58 & $95.08^{\mathrm{a}}$ & $0.25^{\mathrm{b}}$ & 37.65 & 13.68 & 33.01 & $14.23^{\mathrm{a}}$ \\
\hline SEM & & 0.08 & 0.03 & 0.15 & 0.97 & 0.02 & 0.44 & 0.67 & 0.12 & 1.22 \\
\hline & Regular & $2.69^{\mathrm{b}}$ & $0.77^{\mathrm{b}}$ & 3.50 & $95.95^{\mathrm{b}}$ & $0.26^{\mathrm{b}}$ & 37.60 & 14.07 & 33.50 & 12.53 \\
\hline & Protected & $2.89^{\mathrm{a}}$ & $0.84^{\mathrm{a}}$ & 3.52 & $97.90^{\mathrm{a}}$ & $0.29^{\mathrm{a}}$ & 37.44 & 14.83 & 34.10 & 11.29 \\
\hline SEM & & 0.06 & 0.02 & 0.10 & 0.65 & 0.01 & 0.28 & 0.47 & 0.78 & 0.78 \\
\hline
\end{tabular}

Met, Methionine; DFI, daily feed intake; DWG, daily weight gain; FGR, feed:gain ratio; BWi, initial body weight; BWf, final body weight; FFLG, fat free lean gain; LMP, lean meat percentage; BT, backfat thickness; LMA, Longissimus muscle area; PUN, plasma urea nitrogen concentration; SEM, standard error of the mean. Means with different superscript letters $\left({ }^{\mathrm{a}}, \mathrm{b}, \mathrm{c}, \mathrm{d}\right)$ within columns differ statistically $(\mathrm{p} \leq 0.10)$.

\section{Declarations}

\section{Funding}

"Colegio de Postgraduados" provided economic support to conduct this study.

\section{Conflicts of interest}

The authors declare they have no conflicts of interest with regard to the work presented in this report.

\section{Author contributions}

José. L Figueroa-Velasco participated in the experimental design, supervision of the experimental protocol and writing of the manuscript. David Trujano-San Luis conducted the experimental work, laboratory analysis, and wrote the manuscript. José A. MartínezAispuro participated in the experimental design, data collection, statistical analysis and writing of the manuscript. María T. SánchezTorres designed and supervised the study, and revised the final manuscript. María $M$. Crosby-Galván collaborated with laboratory analysis, revised the research proposal and the final manuscript. Agustín Ruíz-Flores revised the research proposal, statistical analysis and the final manuscript. Jose L. Cordero-Mora obtained samples and data, supervised the health status of the pigs and revised the final version of the manuscript. 


\section{References}

Bauchart-Thevret C, Stoll B, Chacko S, Burrin DG. Sulfur amino acid deficiency upregulates intestinalmethioninecycleactivity and suppresses epithelial growth in neonatal pigs. Am J Physiol Endocrinol Metab 2009; 296(6):1239-1250. DOI:https://doi.org/10.1152/ajpendo.91021.2008

Burson D, Berg E. Procedures for estimating pork carcass composition. Pork quality facts. National Pork Producers Council, Des Moines, IA, USA; 2001.

Castellano R, Perruchot MH, Conde-Aguilera JA, Van Milgen J, Collin A, Tesseraud S, Mercier Y, Gondret F. A methionine deficient diet enhances adipose tissue lipid metabolism and alters anti-oxidant pathways in young growing pigs. Plos One 2015; 10(7):e0130514. DOI: https://doi.org/10.1371/journal.pone.0130514

Chaney AL, Marbach EP. Modified reagents for determination of urea and ammonia. Clin Chem 1962; 8:130-132.

Chen Y, Li D, Dai Z, Piao X, Wu Z, Wang B, Zhu Y, Zeng Z. L-methionine supplementation maintains the integrity and barrier function of the small-intestinal mucosa in post-weaning piglets. Amino Acids 2014; 46(4):1131-1142. DOI: https://doi.org/10.1007/s00726-014-1675-5

Conde-Aguilera JA, Cobo-Ortega C, Mercier Y, Tesseraud S, Van Milgen J. The amino acid composition of tissue protein is affected by the total sulfur amino acid supply in growing pigs. Anim 2014; 8(3):401-409. DOI: https://doi.org/10.1017/S1751731113002425

de Oliveira SFC, Pinheiro RW, Fontes DO, Scottá BA, Almeida M, Souza LPO, Vidal TZ. Níveis de metionina+cistina para leitões dos 6 aos $16 \mathrm{~kg}$ submetidos a diferentes graus de ativação do sistema imune. Rev Bras Saúde Prod Anim 2015; 16(4):827-838. DOI: http://dx.doi.org/10.1590/S 1519 99402015000400007

Estación Agro-Meteorológica. 2016. Estación Automática Vantage Pro. Colegio de
Postgraduados, Campus Montecillo. http://www. cm.colpos.mx/meteoro/index.htm (Consulted: september 06, 2019).

García CRF, Malacara ÁOE, Salinas CJ, Torres HM, Fuentes RJM, Kawas GJR. Efecto de la suplementación de lisina sobre la ganancia de peso y características cárnicas y de la canal en cerdos en iniciación. Rev Cient FCV-LUZ 2010; 20(1):61-66.

Kong C, Park CS, Ahn JY, Kim BG. Relative bioavailability of DL-methionine compared with L-methionine fed to nursery pigs. Anim Feed Sci Technol 2016; 215:181-185. DOI: https://doi.org/10.1016/j.anifeedsci.2016.03.011

Norma Oficial Mexicana (NOM-062ZOO-1999). Especificaciones técnicas para la producción, cuidado y uso de animales de laboratorio. Ochoa M. L. I. Diario Oficial de la Federación: México, DF; 2001.

NRC (National Research Council). Nutrient requirements of swine. 11th Ed. Washington, DC, USA: National Academy Press; 2012.

Opapeju FO, Htoo JK, Dapoza C, Nyachoti CM. Bioavailability of methionine hydroxy analog-calcium salt relative to DL-methionine to support nitrogen retention and growth in starter pigs. Anim 2012; 6(11):1750-1756. DOI: https://doi.org/10.1017/S1751731112000869

Pena SM, Lopes DC, Rostagno HS, de Oliveira Silva FC, Donzele JL. Relações metionina mais cistina digestível:lisina digestível em dietas suplementadas com ractopamina para suínos em terminação. R Bras Zootec 2008; 37(11):1978-1983. DOI: http://dx.doi. org/10.1590/S1516-35982008001100012

Piva A, Pizzamiglio V, Morlacchini M, Tedeschi M, Piva G. Lipid microencapsulation allows slow release of organic acids and natural identical flavor along the swine intestine. J Anim Sci 2007; 85(2):486-493. DOI: https://doi.org/10.2527/jas.2006-323

Prandini A, Sigolo S, Morlacchini M, Grilli E, Fiorentini L. Microencapsulated lysine and 
low-protein diets: effects on performance, carcass, characteristics and nitrogen excretion in heavy growing-finishing pigs. J Anim Sci 2013; 91(9):4226-4234. DOI: https://doi.org/10.2527/jas.2013-6412

Qin C, Huang P, Qiu K, Sun W, Xu L, Zhang $X$, Yin J. Influences of dietary protein sources and crude protein levels on intracellular free amino acid profile in the longissimus dorsi muscle of finishing gilts. J Anim Sci Biotechnol 2015; 6(52):1-10. DOI: https://doi.org/10.1186/s40104-015-0052-x

Santos FA, Donzele JL, Oliveira FCS, Oliveira RFM, Abreu MLT, Saraiva A, Haese D, Kill JL. Levels of digestible methionine+cystine in diets for high genetic potential barrows from 95 to 125 kg. R Bras Zootec 2011; 40(3):581-586. DOI: http://dx.doi.org/10.1590/S1516$\underline{35982011000300016}$

Sato H, Seino T, Korayashi A, Murai A, Yugari Y. Determination of the tryptophan content of feed and feedstuffs by ion exchange liquid chromatography. Agric Biol Chem 1984; 48(12):2961-2969. DOI: https://doi.org/10.1080/00021369.1984.10866621

SAS, Statistical Analysis System, Version 9.3. SAS Institute Incorporation. Cary, NC, USA; 2011.

Schwab CG, Orway RS. Methionine supplementation options. Department of Animal and Nutritional Sciences. University of New Hampshire Durham. 2016. DOI: https: / / www.researchgate.net / publication/238748587

Shen YB, Weaver AC, Kim W. Effect of grade L-methionine on growth performance and gut health in nursery pig compared with conventional DL-methionine. J Anim Sci 2014; 92(12):5530-5539. DOI: https://doi.org/10.2527/jas.2014-7830

Stein HH, Seve B, Fuller MF, Moughan PJ, De Lange CFM. Invited review: Amino acid bioavailability and digestibility in pig feed ingredients: terminology and application. J Anim Sci 2007; 85(1):172-180. DOI: https://doi.org/10.2527/jas.2005-742

Wu G, Wu ZL, Dai ZL, Yang Y, Wang W, Liu C, Wang B, Wang J, Yin Y. Dietary requirements of nutritionally nonessential amino acids by animals and humans. Amino Acids 2013; 44(4):1107-1113. DOI: https://doi.org/10.1007/s00726-012-1444-2

Ying Y, Yun J, Guoyao W, Kaiji S, Zhaolai D, Zhenlong W. Dietary L-methionine restriction decreases oxidative stress in porcine liver mitochondria.ExpGerontol2015;65:35-41.DOI: https://doi.org/10.1016/j.exger.2015.03.004

Zanton GI, Bowman GR, Vázquez-Añón M, Rode LM. Meta-analysis of lactation performance in dairy cows receiving supplemental dietary methionine sources or post-ruminal infusion of methionine. J Dairy Sci 2014; 97(11):7085-7101. DOI: https://doi.org/10.3168/jds.2014-8220

Zhang GJ, Xie CY, Thacker PA, Htoo JK, Qiao SY. Estimation of the ideal ratio of standardized ileal digestible threonine to lysine for growing pigs $(22-50 \mathrm{~kg})$ fed low crude protein diets supplemented with crystalline amino acids. Anim Feed Sci Technol 2013; 180(4):83-91. DOI: https://doi.org/10.1016/j.anifeedsci.2013.01.006 